Article

\title{
Cultivating a Value for Non-Human Interests through the Convergence of Animal Welfare, Animal Rights, and Deep Ecology in Environmental Education
}

\section{Helen Kopnina ${ }^{1, *}$ and Brett Cherniak ${ }^{2, *}$}

1 Institute Cultural Anthropology and Development Sociology, Social and Behavioural Sciences, Leiden University, Wassenaarseweg 52, Leiden 2300 RB, The Netherlands

247 Jones Street, Hamilton, Ontario, ON L8R 1X9, Canada

* Authors to whom correspondence should be addressed; E-Mails: h.kopnina@hhs.nl (H.K.); brettcherniak@gmail.com (B.C.); Tel.: +31-645-584-957 (H.K.); +1-519-590-6339 (B.C.).

Academic Editor: Erin Frisk Redman

Received: 25 May 2015 / Accepted: 17 November 2015 / Published: 25 November 2015

\begin{abstract}
While the original objective of environmental education (EE) and education for sustainable development (ESD) acquired an awareness of the natural world and its current plight, animal welfare (AW), animal rights (AR), and deep ecology (DE) have often been absent within EE and ESD. AW and AR focus their attention on individual animals, while the DE perspective recognizes the intrinsic value of the environment. In this article, we shall discuss how the integration of these three approaches within EE/ESD can and should be improved, with particular reference to the ethical underpinnings of educational scholarship and practice. This article will argue that these three positions are well placed to enhance the democratic practices of EE/ESD through the adoption of an inclusive pluralism that embraces representation of non-human species and recognizes their interests.
\end{abstract}

Keywords: animal rights; animal welfare; deep ecology; education for sustainable development; environmental education; environmental ethics 


\section{Introduction}

The objectives of environmental education (EE) are defined as helping students acquire: an understanding of basic ecology, an awareness of the natural world and its current plight, a sensitivity to the need for protecting nature, and the skills to help address environmental challenges [1]. Education for environmental sustainability engages both the macro units of study, such as "nature" or "ecosystems," and the micro, such as species and individual animals, plants, fungi, or bacteria. The scope of this article does not allow for a more detailed discussion of what qualifies as "animals" present in animal rights literature. For the purpose of this article, we shall only refer here to animals as sentient beings, thus a category that can also sometimes apply to plants, fungi, or bacteria. Simultaneously growing alongside EE over the decades, education addressing animal welfare and animal rights has emerged as part of a larger environmental concern [2].

The ethical underpinnings of animal rights (AR), animal welfare (AW) and deep ecology (DE) are based on a number of ethical positions relating to EE's original objectives. These ethical positions range from concern for animal welfare and animal rights on one hand to environmental ethics on the other. According to Tom Regan [3], animal rights are defined as a commitment to the abolition of the use of animals in science; dissolution of commercial animal agriculture and elimination of commercial and sport hunting and trapping. Environmental ethics, in turn, range from anthropocentrism (human-centeredness) to ecocentrism or biocentrism (placing ecosystems or biosphere at the heart of moral consideration) as well as the in-between gradations, including strong and weak anthropocentrism. Norton [4] distinguished between "felt" and "considered" preferences. A felt preference is one that may be temporarily satisfied by some specific experience. A considered preference is arrived at after "careful deliberations." According to Norton, an ethic is strongly anthropocentric if it focuses on felt preferences without reference to socio-cultural context (thus, non-consequentialism) and weak anthropocentrism if it focuses on felt and considered preferences, dependent on one's worldview (thus, consequentialism. Naess [5] drew a distinction between deep and shallow ecology, with the former associated with recognition of intrinsic value of environment beyond its unity, and the latter including human interests. While anthropocentrism assigns moral value to humans only, it can also include consideration of the environment when human welfare is affected, or of animals used for food, research, entertainment or companionship. Generally, non-anthropocentric ethical perspectives are concerned with the preservation of biodiversity and conservation- not so much for its utility to us humans, but for the benefit of entire habitats or species themselves. These general ethical orientations consider the moral position, welfare, or legal rights of either environment or individual animals, or both.

AW refers to the desire to prevent unnecessary animal suffering, and while not categorically opposed to the use of animals, wanting to ensure a good quality of life. AW includes not only the state of the animal's body, but also its feelings or sentience [6]. Animal welfare education (AWE) promotes knowledge, understanding, skills, attitudes and values related to human involvement in the lives of animals [7]. A number of educational programs and specialized courses have been established that address animal welfare from ethical, political, and practical perspectives. The Animal Welfare Institute (AWI), founded in 1951, and the International Fund for Animal Welfare (IFAW), founded in 1969, are both involved in education for animal rights and welfare [8,9]. However, their educational programs are not connected to EE nor education for sustainable development (ESD). 
AR refers to the philosophical belief that animals should have the right to live their lives free of human intervention, opposing the use of some animals by humans [3]. In education, AR has not been taught independently from AWE, nor has "humane education", defined by the Institute for Humane Education as a form of education that "instills the desire and capacity to live with compassion, integrity, and wisdom, but also provides the knowledge and tools to put our values into action in meaningful, far-reaching ways."

Education for DE has been taught as part of outdoor (experience) education when the students are involved in outdoor activities [10] or philosophy courses [11]. AR, AW and DE have routinely been taught in existing courses such as biology, ethics, or sustainability, with independent focus being scarce (e.g., [12]). Within ESD, environmental sustainability concerns are normally displayed along with social and economic objectives, and AR, AW and DE are presented as an ad hoc practice, primarily associated with the conservationist and the naturalist subjects (e.g., [13-16]).

In this article, we shall address the ethical underpinning of the EE/ESD scholarship and reflect upon the position of AR, AW and DE within the established practice. We shall focus on the questions: How is care for ecosystems, biosphere, species or individual animals positioned within EE/ESD? What ethical positions underlie considerations of environment and animals in EE/ESD?

\section{From Ethics to Sustainability}

The complexity of the natural world has necessitated the exploration and development of several nuanced and distinct non-anthropocentric ethics. Kronlid and Öhman [17] (p. 23) have distinguished between five different typologies of non-anthropocentric ethics in the context of EE research: sentientism (non-human animals with the ability to experience pain and suffering have intrinsic value); animal rights (non-human animals with a sense of self have intrinsic value); social animal ethics (non-human animals with the ability to engage in relationships have intrinsic value); biocentrism (all organisms have intrinsic value by virtue of having a good of their own related to their flourishing), and ecocentrism (ecosystems and species have intrinsic value because it is possible to relate to them as separate entities and because they have a capacity to sustain life and well-being in terms of their integrity, stability and beauty). These distinctions allow us to consider a wider range of perspectives, values and situations when discussing the position of non-humans within education practice while bringing to light the many concerns of the natural world.

Many theorists have attempted to demonstrate the precise ways in which deep ecology and animal rights/ethics/liberation are entangled and interdependent, as well as how they differ, for a review of some perspectives see [18]. AR, AW and DE are divided on a number of points but are united in their support of care for the environment and individual animals. The greatest commonality between DE and much of animal ethics is that they remove humans from the moral pedestal and seek recognition of the plight of non-humans. As Jamieson [19] has pointed out, the urgency of environmental predicament and the plight of non-humans does not allow for more internal battles, thus calling different "camps" to combine their knowledge, not to "overwhelm" the status quo with a flurry of "niche" groups.

This plight of non-humans is characterized primarily by the destruction of habitats upon which wildlife is dependent and the abuse of animals used for human consumption through the industrial 
food production system, e.g., concentrated animal feeding operations (CAFOs). Ecocentric scholars have argued that unless the intrinsic value of non-humans is recognized, there will be no institutional guarantees that the interests of other species will be protected and not continually neglected [20-23]. The market economy has been represented as the solution to issues of sustainability, embedding economic reasoning deeply into environmental policy, planning, and practice and ignoring the plight of the planet [24]. Such reasoning led to the subordination of non-humans and their habitats to social and economic objectives $[1,13,17,25,26]$.

This trend of presenting nature as capital and commodity has made its way into educational practice. The literature is replete with references to natural resources, natural capital, and ecosystem services, conceptualizing nature through an anthropocentric, utilitarian lens while the recognition of the intrinsic value of biodiversity seldom appears in the same space. [1,13,17,27]. Environmental "management" of "natural resources" became interlinked with the market mechanisms of "species banking" and "carbon trading." In line with the Brundtland definition of "development that meets the needs of the present without compromising the ability of future generations to meet their own needs," ESD has shifted its focus towards environmental justice, primarily concerned with the distribution of environmental benefits and burdens among human beings [28]. ESD chiefly promotes sustainability, placing its focus on a "sense of justice, responsibility, exploration and dialogue" [29]. In this context, education concerned with animals is not commonly discussed as an integral part of education for sustainability. We shall argue that it is crucial to see AR, AW, and DE connected to the overall goal of enhanced empathy, which is stressed in social equity, as in Norton's convergence theory [4]. Convergence can be illustrated by the consumers' insistence on transparency in our food system, which is linked to the treatment of farm laborers as well as livestock; or address pollution that affects both human and natural systems. For example, as the World Society for the Protection of Animals (WSPA) has outlined, AWE entered ESD through the avenues of: environmental and agricultural sustainability (responsible animal management); human health (good animal care reduces the risk and spread of diseases that can be transmitted to humans and of food poisoning); poverty and hunger reduction (looking after animals properly improves their productivity and helps farmers to provide a secure food supply and income for themselves, helping to alleviate poverty); disaster preparedness and risk reduction (animals are important for people's lives and livelihoods and must be given due consideration in plans for disaster preparedness and response). It is notable that a view of "useful animals" is interlinked with conceptions of stewardship, management, and other optimistic "innovations" [30].

However, we also warn that when developing a framework for connecting AR, AW, and DE to sustainability education - as, for example, through ESD that emphasizes normative competencies, which include values and issues of morality - we need to be careful not to over-emphasize compromise and token accomplishments when harder choices about economic development versus preservation of biodiversity need to be made. "Improving animal productivity" has little relation to ethical concerns about non-humans, giving way to the broad aims embodied by ESD, such as social equality and economic equity (e.g., [31,32]). While there has long been a supposed connection between the conscientious consumption of green products and conservation, empirical evidence from wealthier countries denies that consumer responsibility alone can overcome unsustainability. Nor have multinational corporations shown much transformative power in their ability to alter global unsustainability practices 
or address the mere scale of animal use in industries ranging from food to pharmaceuticals [2,3,5]. Societal concerns do not naturally and automatically seep into educational practice, and neither can we assume that corporate or political leaders can be "taught" to care about non-humans. What can be achieved, however, is the critical awareness of how normative concepts of "sustainable development" or "animal productivity" are used. Yet, this critical reflection and skepticism about the indoctrinating tendencies of normative concepts should not turn into a fear of all types of instrumentality, as we shall explain in more detail below.

Some EE/ESD scholars have expressed their angst of indoctrination leading to behavioral change that "environmentalists" could implant into their pupils' brains, even if this change means a more inclusive recognition of non-humans [33-35]. Illustrating the fear of environmentalism, they have warned against "eco-totalitarianism" [33] (p. 225). Breiting [34] has expressed concern with educators and pupils being used as marionettes by the generalized camp of "environmentalists". A telling example is provided by Bob Jickling. In reflecting upon the controversy about shooting wolves in the Yukon area, Jickling felt that advocating the pro-wolf position as a schoolteacher in a local community would be "neither practically viable nor educationally justifiable" [35] (p. 92). Jickling justifies this position by the need to stay neutral in order to teach students democratic and open values and avoid indoctrination.

Other EE/ESD scholars have tried to bridge the gap between the generalized camps of ecocentric environmentalists and "emancipatory" educators by arguing that educational practitioners and theorists should not continually reproduce a simplified notion of anthropocentrism and non-anthropocentrism [36]. Kronlid and Öhman [17] (p. 34) note that when environmental ethics is used in EE research, the "cross-disciplinary work should take the complexity and pluralism of environmental ethical issues and the variety of sub-positions produced above into consideration" (italics added). This may be seen as another example of the "latent authoritarian tendency" of environmentalists [37] (p. 126): the presumption that open discussions are guaranteed to solve all of our problems and produce the desired results. Rather than dwelling on the anthropocentrism/ecocentrism dichotomy, they suggest that educators should embrace different ethical perspectives and foster democratic learning.

The onus for drawing attention to AW and AR appears to have been left by educationists to outside pressure groups and the media [2], with DE being relegated to the marginal experiential education [10]. With a few exceptions, a couple of educational programs focus on intrinsic values or the rights of animals. This raises a number of ethical questions in both EE/ESD and within the general enterprise of sustainable development: Should future generations of humans have the right to experience wilderness and biological diversity? Does sustainable development concern other species? Do animals and plants have the right to a secure future? [36] (p. 67). Why is teaching for democracy, gender and racial equality and economic equity an expressed aim in most EE/ESD while the ongoing extinction or treatment of animals in the industrial food production system is a marginal concern?

AR, AW and DE have been present $a d$ hoc for a few decades within or outside of EE or ESD, with issues concerning speciesism (discrimination against other species) seen as a footnote in mainstream environmental education journals (for review see [28]). 


\section{Animal Rights, Animal Welfare, and Deep Ecology in Environmental Ethics}

Critics have pointed out that much of the anthropocentric ethics prevalent in EE/ESD is primarily concerned with questions of social and economic equity [28]. "Social equity," for example, usually means "universal participation in global markets that will require continued ecological sacrifices" (e.g., [25]). In fact, the moral imperatives of social and economic equality conveniently serve the global market through the global perpetuation of consumer culture [26]. Considerations of non-humans are marginal in the pluralistic perspective dominated by social and economic agendas [27,28].

Will we even notice when species go extinct, and if we do, what will we notice? Indeed, there are plenty of empirical examples which demonstrate that the extinction of species have not affected food supply chains or human welfare. As witnessed during recent extinctions, few direct negative side effects are experienced by people, aside from some marginal benefits for the pharmaceutical industry or zoos. Thompson [38] and Kareiva et al. [39] have found that we do not need to save every species as humanity is not dependent on them, but should instead embrace human-managed nature and no longer waste time teaching students to care about what is left of the wilderness. This transition of academic discourse toward human-managed nature is part of a more general trend that embraces the domestication of the planet. Yet critics have argued that this instrumental attitude to nature is precisely what has brought us to our current environmental problems [27].

While many different schools of environmental ethicists agree that humans and environment are intimately interrelated, interconnected, and the relationship between the human and non-human worlds is that of mutual reciprocity, more skeptical critics emphasize that this reconciliatory view tends to ignore how economic development destroys entire habitats and distracts public attention from the plight of farm animals or those used for medical experimentation [25]. According to this critique, it is not a question of whether humans and nature are connected or dependent on nature (in a similar way, we could inquire whether the slave owners were really dependent on slaves), but whether these elements of nature-living creatures - have any significant moral status. Is there not a moral need to recognize that we are not the only species on Earth that needs to be considered? To return to the question posed in the introduction, what ethical positions underlie considerations of the environment and animals in EE/ESD?

\section{The Question of Morality}

While there is a shift in public awareness towards recognition of animal welfare concerns, there is no consistent discussion about the scale of instrumental use of other species. The scale of this exploitation, including CAFOs and intensive farming, which relegate billions of animals to short and miserable existences, has increased exponentially alongside human population growth and consumption [25]. While the fate of a single abused dog may capture public attention through the media, there is no consistent discussion about the millions of species "harvested" for consumption, or used for medical experiments.

The philosophical and political difficulty of establishing a non-anthropocentric ethic has led pragmatic theorists to support an "enlightened anthropocentrism" which, whilst recognizing the human-centered reality, claims to be consistent with a high degree of protection for non-human nature (e.g., [4,40,41]). Such a case is based primarily on an empirical claim that the protection of the natural world - including 
animals - is in the interest of humans. However, the pragmatist thinkers reflect that relying on the intrinsic value of non-human animals and the environment is not sustainable and argue that moral anthropocentrism is unavoidable [41,42]. Enlightened anthropocentrism is largely consistent with "the convergence thesis," stating that preservationist and conservationist policies will tend to converge in the long run [43].

For example, biological and organic meat can be good both for farm animals and for human health. Another familiar example is addressing water, soil or air pollution that is likely to harm humans with the positive side-effects it brings for habitats or species. These lead to the type of convergence thinking that assumes a healthy environment caters to human needs and, conversely, that social or economic needs will serve nature. This reliance on perceived interdependence is often seen in EE/ESD. Famously, the Brundtland report speaks of convergence between the three pillars of economic development, social equity, and environmental protection. A similar effort is made to "balance" opposing perspectives, presenting conflicts not in moral (good vs. bad) or rational (right vs. wrong) terms but as a broader exercise in social learning [44] or "learning from sustainable development" [45].

However, others have noted that occasionally the interests of humans and animals (and humans and environment more broadly) coincide, anthropocentrism can make a positive contribution to the evaluation and justification of environmental policy in situations dealing with artificial (human-created or controlled) and not natural systems [46]. Examples of policies addressing artificial systems might include urban air pollution, regulation of greenhouse gases, issues of environmental justice, and the environmental impacts of agriculture. These are largely consistent with conventional sustainability policy, where the environment and individual species or animals are kept in orbit with economics at the center; our destructive systems become more sustainable, leading us to believe that we are helping the environment as a whole. The environment in this policy will be considered if and only if a degrading environment might undermine ongoing development [47]. However, in cases of largely natural systems, wilderness preservation and the protection of endangered species, a moral monism [48] embracing ecocentric, biocentric or animal-centric positions offers a wider protection for environment than an anthropocentric-dominant pluralism. According to Katz "there is a clear difference between anthropocentric and nonanthropocentric justifications for environmental policy, and in these situations I remain committed (mercilessly) to nonanthropocentrism" [46] (p. 390).

Naess argued that sustainability hinges on a consistent education curriculum which is tied back to a well-informed understanding of the state of the planet [49]. The non-anthropocentric environmental ethics calls for a new ethic, not beholden to any previously dominant stream of thought and not dependent on the shifting cultural morality of today [19]. An imperative to protect and preserve (or, to use a more popular term, to accept stewardship of) non-humans could stem from human reason, or love, or sense of duty and responsibility [47].

Yet, this ethic is now in short supply if we notice how mercilessly the processes endangering habitats, species and individual animals have expanded their hold within public imagination, and that of EE/ESD scholars. The critics have noted that the brainwashed, anthropocentric ideology that has taken hold of the supposedly free "choices" being made in neoliberal education systems is not likely to offer a way forward as the choices given still find themselves under the influence of this anthropocentric ideology [24,50,51]. 


\section{Reflection}

In answering the question, "How is care for ecosystems, biosphere, species or individual animals positioned within EE/ESD?" we note that this possibility is contingent upon a socio-political and cultural context permitting an ecocentric ethic to be recognized as a necessary contribution to environmental integrity. An EE/ESD that is already respective and inclusive of AW, AR and DE could help to create this context. As with other socio-political changes, education plays an essential role in change to society as a whole and the political institutions within. Still, we need to be aware that if inroads are only made in education, this progress might be lost once students leave the classroom if the greater context is not in place, thus a wider societal transformation that offers an ethical support base for AW, AR and DE would be close to a requirement. An education is pointless if students enter a society that does not allow for the inclusive support of the values and perspectives they have learned.

Encouragingly, Andrew Dobson has suggested that non-human animals could be democratically represented through proxy representatives elected explicitly to promote their interests, occurring through real elections in which candidates are elected in the present system [22]. In his later work, Dobson argued that since animals cannot speak themselves, the ability to recognize their "voice" through their representatives, is of crucial importance if they are to be considered as democratic (with "demos" in this case extending to non-humans) participants [23]. In this case we need to note that the voice of animals (as well as fungi, algae, etc.) can be extended to habitats and ecosystems by combining common threads from AR, AW and DE. Generally, these common threads are based on the philosophy of inclusion of ecosystems, species or non-human individuals within the sphere of moral consideration, based on biophilia (love of nature), and, particularly in the case of DE, realization of intimate interconnectedness between humans and natural elements.

While DE's philosophy of inclusion might be too weak in the face of dominant anthropocentric neo-liberal ideology, AR might be too "strong." Presently, AR is often perceived as subversive or threatening. For example, Animal Liberation Front (ALF) and Earth Liberation Front (ELF) activists are seen as dangerous and radical [52-54]. While such organizations exhibit a concern that is desirable if non-human interests are to be upheld, they do not address the social, economic, or cultural forces that shape the general public's attitudes. However, it is still precisely this type of "radical" attitude that is needed to reverse the impetus of the presently taken-for-granted anthropocentric ethics that governs much of EE/ESD educational practice. This is not to imply that the acts of property destruction that these activists have committed are recommended for educators to teach to students, but rather understanding the type and development of commitment, rage, as well as selfless love of non-human beings, be they clear-cut forests or animals used for laboratory experiments that deserve educators' attention. Richard Kahn discussed the need of radical reorientation of education toward ecological concerns and other species, examining how the essence of ALF and ELF's ideas (although certainly not the methods) can be used to inspire educational practice beyond the current status quo [53]. Integrating the perspectives from groups such as ELF in the curriculum was discussed by Kopnina $[55,56]$. It was suggested that we can draw inspiration for educational practice from eco-pedagogy, which places ecological integrity as well as animal welfare at the center of sustainability challenges. An example of this is given by Kopnina in her discussion of exposing business students to radical environmental activism 
through the in-class viewing of the documentary film, If a Tree Falls (2011), directed by Marshall Curry and Sam Cullman about the rise and fall of ELF. As one of the reviewers of the film wrote:

What is interesting is that even while we don't agree with what the ELF is doing, the film gives us images that allow us to understand their point of view. We see footage of trees that have stood for thousands of years, blindly cut down. We see horse mills, with hundreds of dead horses hung from the ceiling. We see the heartbreaking sight of a group of legendary trees sawed down to make a parking lot... We see the protesters themselves, camped out in the trees that are to be cut down, beaten unmercifully by the local police... The irony is that the members of the group who are clearly guilty of vandalism haven't done any physical harm to other human beings but are being beaten down by law enforcement as if they were murderers [57].

After viewing the film, the business students exhibited a shift in their ethical thinking and an increase in awareness of ecocentric concerns. The film made students question the activists' reasons behind their level of commitment, contemplating what makes some people join ALF and ELF and others refrain. In written assignments following the viewing of the film, students were able to separate the beliefs of ALF/ELF from the stigma attached to their actions. The students realized that the "radical" or "terrorist" label of the activism featured in the film could indeed be disputed - to quote a law enforcement officer in the film, "One man's terrorist is another man's freedom fighter."

More generally, returning to educational practice and questions which researchers should explore further: Do we need their "strong" views throughout the entire process, or just to begin "the shift"? What creates a positive feeling about non-humans, and how can we educators help to spread that? Would aligning EE/ESD with some of the aims of radical organizations, or only their attitudes, provide an easy target for opposition?

This shift in awareness is also crucial in relation to AR and AW. Regarding animal ethics and welfare in education, Kelly reflected that "those who know it is not necessary to kill animals for food or fight them as entertainment have an ethical responsibility to teach other humans how to eat without killing, how to be entertained without exploiting" [58]. According to Kelly, this type of education triggering a shift in awareness and ethical consideration of non-humans would "allow researchers to devote research to making animals' lives better without worrying about the accusation that they should be devoting their time to less trivial matters; and would function to make education a far less anthropocentric endeavor" [58] (p. 45). This research could form a base, noted Kelly, to teaching about legal protection of animals that (1) emphasize respect for animals, even when others understand this as moral proselytizing; (2) teach that it is wrong to continue practices and habits that are exploitive of animals when alternative practices are possible; (3) design life-skills curricula that help those who cannot envision the feasibility of these alternative practices to do so (such as vegetarian cooking); (4) de-anthropocentrize the mission of educational institutions; and (5) discount any unnecessary piece of knowledge gained at the expense of animals' welfare as unworthy of academic attention [58] (p. 45). These steps will require continuous representation of non-human interests by eco-advocate educators.

Thus, the role of representation of non-human interests through eco-advocates $[59,60]$ is essential if educational researchers and practitioners are to move beyond the status quo of conventional plurality. In discussing environmental justice (equal distribution of environmental risks and benefits, including 
to the non-human species) and democracy, Dobson emphasized that "if harm is being done, then more justice rather than more talking is the first requirement" [22] (p. 26).

Because other species cannot engage in "pluralistic" discussion due to their inability to speak our language, the participation of educators who represent non-human "voices" is essential. Following this, the insistence that the distinction between anthropocentric and non-anthropocentric ethics is not relevant for $\mathrm{EE} / \mathrm{ESD}$ (e.g., [17,36]) is counterproductive to the effort to expand the pedestal of moral significance to the non-humans. Questioning anthropocentrism is far more than an academic exercise of debating the dominant cultural motif of placing humans at the center of material and ethical concerns. It is a fertile way of shifting the focus of attention away from the problem-symptoms of our time to the investigation of root causes. And certainly the dominant beliefs, values, and attitudes guiding human action constitute a significant driver of the pressing problems of our day [61].

The misplaced fear of eco-totalitarianism in education [33] fails to account for the one-species' totalitarianism over non-human beings, denying eco-advocates the right of providing the "voice" to the millions in need of urgent protection. The dominant form of pluralism is often reflective of the neoliberal model in which individual choices are intertwined with free market thinking at the expense of ecological concerns [50,51]. Anthropocentric pluralism places humanity outside and above the natural world, and its constructed distinction and artificial perch offer the illusion of superiority and a transient experience of "wealth" at the expense of others, while what is sacrificed is the very source from which true power flows: abundance, creativity, unexpectedness, reciprocity, and mutual flourishing [61]. One-species-only pluralism leads educators to think that they give students choices to choose plural perspectives, while the choices are between different shades of anthropocentrism.

Inclusive pluralism embraces non-human representation, while human eco-advocates "speak for nature" [62] and billions of Earth's citizens. As a starting point, we could discuss what these non-human voices are exactly saying, and whether some should count more than others, and why some educators should claim to speak for them. Without presuming to know the answer to either of these questions, we support one simple claim: that sentient beings, from orangutans to plants, want to survive, and it is our shared responsibility as members of one single species that both endangers and can act on behalf of their survival, to consider them in our 'pluralist' ethics and education. An inclusive pluralism recognizes plurality of choices of all Earth's citizens, not just those of one species. Andrew Dobson's work in relation to democratic inclusion of non-humans [22,23] as well as Arne Naess's work $[5,49]$ on how different forms of respect and inclusion of non-humans might be grounded provides hopeful directions for consequent research on inclusive pluralism in educational contexts.

However, we realize that incorporating environmental ethics, animal welfare and animal rights into a seamless synthesis easily taught to students can be difficult. There are great conceptual difficulties involved in extending ethics beyond its current application. The strength of animal ethics lies not in incorporating it as part of environmental ethics, which itself seems difficult to subsume under current societal ethics. How does one extend our social ethic to non-sentient and abstract entities such as wilderness areas or even species? The extension of ethics to animals was accomplished in the 70's by various philosophers including Singer and Rollin when they demonstrated the absence of morally relevant differences between humans and animals, and the presence of morally relevant similarities. 
It is in fact a far more difficult task to extend moral status to entities not continuous in traits with humans. Yet, if we despair, no change is likely to come.

\section{Hopeful Directions}

Examples of educational practice that integrate inclusive pluralism in which non-human agents are recognized as potential contributors to diversity perspectives include conservation education [63-65], outdoor education [66,67], education for deep ecology (e.g., [10,11,68]), AWE [2] and post-humanist education $[69,70]$. All these different directions offer a hope of restoration-not just that of nature and animal welfare, but also of ourselves as caring educators and students. As Richard Louv [71] (p. 226), the author of a popular book Last Child in the Woods has stated, "An environment-based education movement - at all levels of education - will help students realize that school isn't supposed to be a polite form of incarceration, but a portal to the wider world" and, as this article makes clear, that wider world includes the inner world. This wider world includes the possibility that lecturers could transmit to their students the ability to transcend the top-down sustainable development that is usually based on control rather than compassion. Just as many conservationists are more interested in increasing their capacity for empathy than for control, they are also frequently interested in communicating to larger audiences how and why their knowledge of nature leads them to love nature [72]. In the words of Vucetich and Nelson [72] (p. 13), knowing conservation's role in society requires knowing how and why populations and ecosystems are valuable. In particular, we need to know how they are valuable beyond their utility to humans - and this is the task that EE and ESD are well suited to undertaking. However, EE/ESD need to be reoriented toward a clearer distinction between what is socially and economically defined as sustainability and what is ecologically defined sustainability - in other words, the difference between sustainable development as a slogan that implies sustaining economic growth, and environmental sustainability that underlies long-term survival of social, economic and natural systems [73].

A hopeful direction for non-anthropocentric education includes initiatives by a number of charities and foundations. The Foundation for Deep Ecology (FDE) supports education and advocacy on behalf of wild Nature, educating citizens that stopping the global extinction crisis and achieving true ecological sustainability will require rethinking our values as a society. FDE argues that "present assumptions about economics, development, and the place of human beings in the natural order must be reevaluated." FDE's educational programs support restoration of "traditional knowledge, values, and ethics of behavior that celebrate the intrinsic value and sacredness of the natural world and give the preservation of Nature prime importance," thereby introducing students to broader topics of sustainability with nature and animals as focal points [74]. In a similar effort, the Rewilding Foundation [75] participates in ecological education and participatory citizen science projects.

Another hopeful direction is integrating AR, AW, and DE within national platforms of EE and ESD, as, for example, the inclusion of Animals (with subsections specified e.g., "Animal welfare", and "Endangered species") by the National Association for Environmental Education UK [76]. At present, these topic sections are empty, implying that it is only a gesture of good will. Also in England, charities like the Royal Society for the Prevention of Cruelty to Animals (RSPCA) offer free training and support for professionals who work with children and young people, stating that their educational 
mission is to help students to develop informed, responsible and active citizens [77]. Tellingly, RSPCA combines the elements of AR, AW and DE by offering both domestic animal-oriented as well as wilderness-oriented curricula through their cooperation with animal shelters, an outdoor education center and a wildlife hospital. People for the Ethical Treatment of Animals (PETA) is the largest animal welfare organization in the world and also allocates education a special role, linking the values encompassing respect for animals, nature, and other human beings, as well as active citizenship:

Teaching kids to have compassion and empathy for their furry, feathered, and finned friends is vital for preventing cruelty to animals as well as in raising them to respect and treat those who are different from them with kindness [78].

These are some among many promising paths that integrate true pluralism by which we mean inclusion of all species into moral consideration and responsible citizenship within and beyond EE and ESD.

\section{Conclusions}

In this article, it was argued that education for sustainability should consider integrating animal rights, animal welfare, and deep ecology (DE) into the core of environment education (EE) and education for sustainable development (ESD) and that these three directions should guide education for sustainability. The instrumental attitude to nature appears to be insufficient for protection of the most vulnerable elements of the environment, or for addressing animal welfare or animal rights, and raising ethical objectives to the anthropocentric view of nature in education. Conservation education, education for deep ecology and education for animal rights can be seen as education that embraces a truly plural position that recognizes diversity of all species. This position would entail a critical education exposing the deficiencies of the mainstream anthropocentric ethics. This might necessitate a continuous affirmative action program as, unlike disenfranchised humans, non-humans will never be able to speak, even when threatened with extinction.

Mike Appleby, an animal welfare scientist was once asked: "What should we do about animal welfare?" He replied: "The answer, ladies and gentlemen, is 'More'." [79]. The same could be said about the question of what should be done about ethical considerations of environment and animals in EE and ESD [60]. What precise shape such recognition will take in both societal and educational discourse still needs to be discussed (e.g., should we oppose all research on animals, or only that which is particularly cruel and not for any meaningful purpose, i.e., cosmetics?). The need for this urgent discussion should be a starting point. While we as researchers and academics would certainly benefit from extended discussion of how the non-human voices can be best represented and by whom, the move toward recognition that the very survival of these non-humans is at stake deserves to be recognized in education for sustainability. This type of change will require affirmative action programs on behalf of what is left of wild Nature and of a wonderful human capacity for empathy and compassion.

\section{Author Contributions}

Helen Kopnina conceived and set out the initial purpose of the work. Helen Kopnina and Brett Cherniak analyzed the relevant material. Helen Kopnina provided extensive experience in environmental education and animal rights education research. Brett Cherniak contributed critical 
discourse and experience in the democratic element of environmental education. Helen Kopnina and Brett Cherniak thoroughly edited the article throughout its development and review process. Helen Kopnina and Brett Cherniak agreed and reviewed upon all changes before any round of submissions. Helen Kopnina and Brett Cherniak wrote the paper.

\section{Conflicts of Interest}

The authors declare no conflict of interest.

\section{References}

1. UNESCO. The Belgrade Charter; UNESCO: Paris, France, 1976.

2. Marsden, W.E. Animal welfare issues in geography and environmental education: Some British historical perspectives. Int. Res. Geogr. Environ. Educ. 2001, 10, 394-410.

3. Regan, T. A Case for Animal Rights. In Advances in Animal Welfare Science; Fox, M.W., Mickley, L.D., Eds.; The Humane Society of the United States: Washington, DC, USA, 1986; pp. 179-189.

4. Norton, B.G. Environmental ethics and weak anthropocentrism. Environ. Eth. 1984, 6, 131-148.

5. Naess, A. The shallow and the deep: Long-range ecology movement. Inquiry 1973, 16, 95-99.

6. Hewson, C. What is animal welfare? Common definitions and their practical consequences. Can. Vet. J. 2003, 44, 496-499.

7. World Society for the Protection of Animals. Education for Sustainable development. Available online: http://www.animalmosaic.org/Images/Education\%20for\%20Sustainable\%20Development tcm46-29460.pdf (accessed on 21 November 2015).

8. Animal Welfare Institute. Humane education. Available online: https://awionline.org/content/ humane-education (accessed on 21 November 2015).

9. International Fund for Animal Welfare. Available online: http:/www.ifaw.org/united-states/ our-work/education (accessed on 21 November 2015).

10. LaChapelle, D. Educating for deep ecology. J. Exp. Educ. 1991, 14, 18-22.

11. Drengson, A.R. Introduction: Environmental crisis, education, and deep ecology. Trumpeter 1991, 8, 97-98.

12. Root-Bernstein, M.; Root-Bernstein, M.; Root-Bernstein, R. Tools for thinking applied to nature provide an inclusive pedagogical framework for environmental education. Fauna Flora Int. Oryx 2014, 3, 1-9.

13. Sauvé, L. Currents in environmental education: Mapping a complex and evolving pedagogical field. Can. J. Environ. Educ. 2005, 10, 11-37.

14. Glasser, H. Learning Our Way to a Sustainable and Desirable World: Ideas Inspired by Arne Naess and Deep Ecology. In Higher Education and the Challenge of Sustainability: Problematics, Promise, and Practice; Corcoran, P.B., Wals, A.E.J., Eds.; Springer Netherlands: New York, NY, USA, 2004; pp. 131-148. 
15. Gorski, P.C. Critical ties: The animal rights awakening of a social justice educator. 2009. Available online: http://www.edchange.org/publications/animal-rights-social-justice.pdf (accessed on 21 November 2015).

16. Hickman, J.A. Personal care products council: An animal cruelty analysis. 2010. Available online: http://www.edchange.org/multicultural/humane/pcpc.pdf (accessed on 21 November 2015).

17. Kronlid, D.O.; Öhman, J. An environmental ethical conceptual framework for research on sustainability and environmental education. Environ. Educ. Res. 2013, 19, 21-44.

18. Garner, R. Environmental Politics, Animal Rights and Ecological Justice. In Sustainability: Key Issues; Kopnina, H., Shoreman-Ouimet, E., Eds.; Routledge Earthscan: New York, NY, USA, 2015.

19. Jamieson, D. Animal liberation is an environmental ethic. Environ. Values 1998, 7, 41-57.

20. Eckersley, R. Liberal democracy and the rights of nature: The struggle for inclusion. Environ. Polit. 1995, 4, 169-198.

21. Eckersley, R. The Green State: Rethinking Democracy and Sovereignty; MIT Press: London, UK, 2004.

22. Dobson, A. Citizenship and the Environment; Oxford University Press: Oxford, UK, 2003.

23. Dobson, A. Listening for Democracy; Oxford University Press: Oxford, UK, 2014.

24. Washington, H.G. Human Dependence on Nature; Routledge: New York, NY, USA, 2013.

25. Crist, E. Ecocide and the extinction of animal minds. In Ignoring Nature no More: The Case for Compassionate Conservation; Bekoff, M., Ed.; Chicago University Press: Chicago, IL, USA, 2013; pp. 45-53.

26. Crist, E. Abundant Earth and Population. In Life on the Brink: Environmentalists Confront Overpopulation; Cafaro, P., Crist, E., Eds.; University of Georgia Press: Athens, GA, USA, 2012; pp. 141-153.

27. Bonnett, M. Sustainable development, environmental education, and the significance of being in place. Curr. J. 2013, 24, 250-271.

28. Kopnina, H. Education for sustainable development (ESD): The turn away from "environment" in environmental education? Environ. Educ. Res. 2012, 18, 699-717.

29. Nevin, E. Education and sustainable development. Policy Pract. A Dev. Educ. Rev. 2008, 6, 49-62.

30. Jickling, B.; Wals, A.E.J. Globalization and environmental education: Looking beyond sustainable development. J. Curric. Stud. 2008, 40, 1-21.

31. UNESCO. United Nations Decade of Education for Sustainable Development (2005-2014). In Framework for the International Implementation Scheme; UNESCO: Paris, France, 2005; Volume 32C.

32. Wals, A.E.J. Shaping the Education of Tomorrow: 2012 Full-Length Report on the UN Decade of Education for Sustainable Development; UNESCO: Paris, France, 2012.

33. Wals, A.E.J.; Jickling, B. "Sustainability" in higher education: From doublethink and newspeak to critical thinking and meaningful learning. Int. J. Sustain. High. Educ. 2002, 3, 221-232.

34. Breiting, S. Issues for environmental education and ESD research development: Looking ahead from WEEC 2007 in Durban. Environ. Educ. Res. 2009, 15, 199-207. 
35. Jickling, B. Wolves, Ethics and Education: Looking at Ethics through the Yukon Wolf Conservation and Management Plan. In A Colloquium on Environment, Ethics and Education; Jickling, B., Ed.; Yukon College: Whitehorse, YT, Canada, 1996; pp. 158-163.

36. Öhman, J.; Östman, L. Clarifying the ethical tendency in education for sustainable development practice: A wittgenstein-inspired approach. Can. J. Environ. Educ. 2008, 13, 57-72.

37. Torgerson, D. The Promise of Green Politics: Environmentalism and the Public Sphere; Duke University Press: Durham, NC, USA, 1999.

38. Thompson, K. Do We Need Pandas? The Uncomfortable Truth about Biodiversity; UIT Cambridge Ltd.: Cambridge, UK, 2010.

39. Kareiva, P.; Lalasz, R.; Marvier, M. Conservation in the anthropocene: Beyond solitude and fragility. Breakthr. J. 2011, 27-29. Available online: http://thebreakthrough.org/index.php/ journal/past-issues/issue-2/conservation-in-the-anthropocene (accessed on 21 November 2015).

40. Barry, J. Rethinking Green Politics: Nature, Virtue and Progress; Sage: London, UK, 1999.

41. Hui, K. Moral anthropocentrism is unavoidable. Am. J. Bioeth. 2014, 14, 25.

42. Light, A. Compatibilism in Political Ecology. In Environmental Pragmatism; Light, A., Katz, E., Eds.; Routledge: New York, NY, USA, 1996.

43. Norton, B.G. Conservation and preservation: A conceptual rehabilitation. Environ. Eth. 1986, 8, 195-220.

44. Wals, A.E.J. Between knowing what is right and knowing that it is wrong to tell others what is right: On relativism, uncertainty and democracy in environmental and sustainability education. Environ. Educ. Res. 2010, 16, 143-151.

45. Van Poeck, K.; Vandenabeele, J. Learning from sustainable development: Education in the light of public issues. Environ. Educ. Res. 2012, 18, 541-552.

46. Katz, E. A pragmatic reconsideration of anthropocentrism. Environ. Eth. 1999, 21, 377-390.

47. Rolston, H., III. Environmental Ethics for Tomorrow: Sustaining the Biosphere. In Sustainability: Key Issues; Kopnina, H., Shoreman-Ouimet, E., Eds.; Routledge Earthscan: New York, NY, USA, 2015.

48. Callicott, J.B. The pragmatic power and promise of theoretical environmental ethics. Environ. Values 2002, 11, 3-25.

49. Naess, A. Beautiful action. Its function in the ecological crisis. Environ. Values 1993, 2, 67-71.

50. Bansel, P. Subjects of choice and lifelong learning. Int. J. Qual. Stud. Educ. 2007, 20, 283-300.

51. Davies, B.; Bansel, P. Neoliberalism and education. Int. J. Qual. Stud. Educ. 2014, 20, 247-259.

52. Liddick, D.R. Eco-terrorism: Radical Environmental and Animal Liberation Movements; Praeger Publishers: Santa Barbara, CA, USA, 2006.

53. Kahn, R. Critical Pedagogy, Ecoliteracy and Planetary Crisis: The Ecopedagogy Movement; Peter Lang: New York, NY, USA, 2010.

54. Kopnina, H. The Lorax complex: Deep ecology, ecocentrism and exclusion. J. Integr. Environ. Sci. 2012, 9, 235-254.

55. Kopnina, H. If a tree falls: Business students' reflections on environmentalism. Int. J. Environ. Sustain. Dev. 2014, 8, 311-329. 
56. Kopnina, H. If a tree falls and everybody hears the sound: Teaching deep ecology to business students. J. Educ. Sustain. Dev. 2015, 9, 1-16.

57. IMDB Film Reviews. If a Tree Falls: A Story of the Earth Liberation Front. Available online: http://www.imdb.com/title/tt1787725/reviews (accessed on 21 November 2015).

58. Kelly, S. Geschlecht, speciesism, and animal rights in Leopold von Sacher-Masoch. J. Crit. Anim. Stud. 2014, 12, 28-50.

59. Lidskog, R.; Elander, I. Addressing climate change democratically. Multi-level governance, transnational networks and governmental structures. Sustain. Dev.2009, 18, 32-41.

60. Kopnina, H.; Gjerris, M. Are some animals more equal than others? Animal rights and deep ecology in environmental education. Can. J. Environ. Educ. 2015, 20, 109-123.

61. Crist, E.; Kopnina, H. Unsettling anthropocentrism. Dialect. Anthropol. 2014, 38, 387-396.

62. O'Neill, J. Who Speaks for Nature? In How Nature Speaks: The Dynamics of the Human Ecological Condition; Haila, Y., Dyke, C., Eds.; Duke University Press Books: Durham, NC, USA, 2006.

63. Norris, K.S.; Jacobson, S.K. Content analysis of tropical conservation education programs: Elements of success. J. Environ. Educ. 1998, 30, 38-44.

64. Goodall, J. Caring for People and Valuing Forests in Africa. In Protecting the Wild: Parks and Wilderness, The Foundation for Conservation, Wuerthner, G., Crist, E., Butler, T., Eds.; The Island Press: Washington, DC, USA; London, UK, 2015; pp. 21-26.

65. Noss, R.F.; Dobson, A.P.; Baldwin, R.; Beier, P.; Davis, C.R.; DellaSala, D.A.; Francis, J.; Locke, H.; Nowak, K.; Lopez, R.; et al. Bolder Thinking for Conservation. In Protecting the Wild: Parks and Wilderness, The Foundation for Conservation; Wuerthner, G., Crist, E., Butler, T., Eds.; The Island Press: Washington, DC, USA; London, UK, 2015; pp. 17-21.

66. Sandell, K.; Öhman, J. Educational potentials of encounters with nature: Reflections from a Swedish outdoor perspective. Environ. Educ. Res. 2010, 16, 113-132.

67. Galen D’Amato, L.; Krasny, M.E. Outdoor Adventure Education: Applying Transformative Learning Theory to Understanding Instrumental Learning and Personal Growth in Environmental Education. J. Environ. Educ. 2011, 42, 237-254.

68. Glasser, H. Naess's deep ecology: Implications for the human prospect and challenges for the future. Inq. Interdiscip. J. Philos. 2011, 54, 52-77.

69. Bonnett, M. Retrieving nature: Education for a post-humanist age. J. Philos. Educ. 2003, 37, 551-730.

70. Bonnett, M. Sustainability, the Metaphysics of Mastery and Transcendent Nature. In Sustainability: Key Issues; Kopnina, H., Shoreman-Ouimet, E., Eds.; Routledge Earthscan: New York, NY, USA, 2015.

71. Louv, R. Last Child in the Woods: Saving Our Children from Nature-Deficit Disorder; Workman Publishing Company: New York, NY, USA, 2008.

72. Vucetich, J.A.; Nelson, M.P. The Infirm Ethical Foundations of Conservation. In Ignoring Nature No More: The Case for Compassionate Conservation; Bekoff, M., Ed.; University of Chicago Press: Chicago, IL, USA, 2013; pp. 9-25.

73. Washington, H. Demystifying Sustainability: Towards Real Solutions; Routledge: London, UK, 2015. 
74. Foundation for Deep Ecology. Available online: http://deepecology.org/mission.htm (accessed on 23 November 2015).

75. Rewilding Foundation. Available online: www.rewildingfoundation.org (accessed on 23 November 2015).

76. National Association for Environmental Education (UK). Available online: http://naee.org.uk/ (accessed on 23 November 2015).

77. Royal Society for the Prevention of Cruelty to Animals. Available online: http://education.rspca.org.uk/education/home (accessed on 23 November 2015).

78. PETA Kids. Available online: http:/www.petakids.com/parents/teaching-compassion/ \#ixzz3LXBoruUv (accessed on 21 November 2015).

79. Hewson, C. Focus on animal welfare. Can. Vet. J. 2003, 44, 335-336.

(C) 2015 by the authors; licensee MDPI, Basel, Switzerland. This article is an open access article distributed under the terms and conditions of the Creative Commons Attribution license (http://creativecommons.org/licenses/by/4.0/). 